\title{
Future agricultural water demand under climate change in Saskatchewan, Canada
}

\author{
S. Kulshreshtha \& C. Nagy \\ Department of Bioresource Policy, Business and Economics, \\ University of Saskatchewan, Canada
}

\begin{abstract}
Climate change is highly relevant in any forecast of water demand in the future. There is enough scientific evidence now that makes climate change serious and compelling. In this study, two major effects of climate change for agriculture were included: (1) change in average temperature (and resulting higher evapotranspiration); (2) increased frequency of extreme dry events. Changes in water demand level were first estimated for a river basin by type of demand, and then aggregated to the Province. Total agricultural water demand was divided into five major types. Results suggest that water demand would increase through two types of sources: (1) demand for irrigation by producers; (2) demand for water for stockwatering purposes. During the 2010-2060 period, total agricultural water demand in the province will increase from 656 thousand dam $^{3}$ to 1.3 million dam ${ }^{3}$ under a baseline scenario, but to 1.66 million dam $^{3}$ under climate change - an increase of $24.3 \%$ resulting from climate change.

Keywords: climate change, agriculture, water demand, Saskatchewan, irrigation, stockwatering.
\end{abstract}

\section{Introduction}

Within only a few years, global warming has been transformed from scientific speculation to an environmental threat of world-wide concern [1]. This phenomenon, now termed as climate change, according to the IPCC [2] is unequivocal, and since the 1950s, many of the observed changes are unprecedented over decades to millennia. Climate change is highly relevant in any forecast of future water demand. The essential question is whether Canadians, especially those in various Saskatchewan River Basins, can manage a change in 
water resources that they put on their crops, run through their turbines, and pipe into their homes (paraphrased from [3]). This study was undertaken to shed some light on the change in water demand for agriculture under a climate change scenario.

\section{Agricultural water demand}

Total agricultural water demand in Saskatchewan was estimated as a sum of five individual demands: (i) irrigation; (ii) dryland production; (iii) livestock production; (iv) greenhouses and nurseries; (v) aquaculture. Of these, the last two demands were assumed to be unaffected by climate change, since greenhouses are climate controlled, and aquaculture does not use any water directly. Projection of future water demand for agriculture was made for the years 2020, 2040 and 2060.

\section{Nature of climate change for Saskatchewan}

Many significant changes in climatologically related variables have been credited to climate change. These include: (i) an increase in average temperature; (ii) higher variability in average precipitation; (iii) distribution of precipitation and its form (more in the form of rain and less as snow); (iv) higher frequency of extreme events; (v) a rise in sea level. It should be noted that the last impact is not relevant to the Province of Saskatchewan, since the region is far from coastlines. Related to water resources, Lemmen and Warren [4] have suggested that, in Canada, climate change would affect us significantly through: (1) changes in annual stream flow, possible large declines in summer rainfall, leading to a shortage of supply; (2) increased likelihood of severe drought, increased aridity in semiarid zones; (3) increases or decreases in irrigation demand and water availability. These changes would lead to many notable concerns: (1) implications for agriculture, hydroelectric power generation, ecosystems, and water apportionment; (2) losses in agricultural production, accompanied by changes in land use; (3) uncertain impacts on farm sector incomes, groundwater, stream flow, and water quality. The same study also noted that climate change may also affect water demand. In addition to population growth and wealth distribution, climate change may increase the demand for water because of higher temperatures and drier conditions.

Two major changes that would affect water demand under an altered climate are the change in average temperature (and resulting evapotranspiration) and increased frequency of extreme events. Two types of extreme events are expected in the future: extreme dry events, called droughts (single period, back-to-back droughts and longer multi-period droughts), and extreme wet events (high rainfall and /or intense rainfall in a short period of time), resulting in floods in some regions. It was assumed that the latter types of events would not affect water demand in the region. Incidence of droughts longer than a year is estimated to triple in frequency under climate change [5]. It seems strange, but with the enhancement of the global hydrological cycles, not only does drought become worse, but also extreme precipitation and associated excessive moisture or flooding can increase. However, this has little impact on water demand. 
In spite of the serious nature of climate change-related events, very few studies have been undertaken for this subject for the region. Other studies have suggested that implications of climate change on water demand may come not only through the direct impact of climate characteristics, but also through indirect linkages with water quality and water availability.

\subsection{Incorporation of climate change in water demand forecasting}

Water demand for agriculture would be affected by change in the temperature and precipitation, and in the frequency of extreme events such as droughts. The impact of each of these factors is described below.

\subsubsection{Effect of temperature change}

Using the Canadian Climate Change Scenarios Network database, a $+3.5^{\circ} \mathrm{C}$ change for 2060 in the average monthly normal was used to adjust current water demand coefficients. Water demand was estimated using this increase in temperature for irrigation, dryland production and livestock production activities.

Water demand levels for irrigation were estimated as a product of irrigated area and water use coefficient. A warmer climate to 2060 could also favor more corn production, as corn is better adapted to taking advantage of the elevated temperature. However, corn has a higher water demand coefficient, compared to present feedgrains. In addition, changing climate may induce more feedlots and corn-based ethanol production.

\subsubsection{Effect of extreme events}

Another aspect of climate change is the frequency of extreme events - droughts and excessive rains. Based on past yield records, it appears that during the last 50 years, there have been four major droughts - 1961, 1988, 2001, and 2002 [6]. Recent droughts and excessive moisture events can be considered harbingers of the extremes that are likely to occur. As noted above, studies have also predicted an increased frequency of extreme events - both droughts and intense rains over the same time period (the latter may perhaps compensate the effect of drought conditions in some years). Given that under flood situations water demand will not change, this aspect of climate change was not included in the analysis.

A precise forecast of drought events is very complex. For this study, estimates were made using a projection methodology. It was assumed that drought frequency by 2020 will remain unchanged (from the current $8 \%$ ). As noted above, by 2090, drought frequency is expected to triple. A straight line projection was used to estimate the future frequency of droughts here, producing estimated frequencies of $13 \%$ by 2040 and about $18 \%$ by 2060 .

\section{Impact on irrigation water demand}

Future irrigation water demand was derived from future irrigated area and water demand coefficients under normal conditions and climate change. The estimation of demand for water to irrigate crop and hay land is dependent on a number of factors: crops grown, growing and non-growing season precipitation, soil 
water-holding capacity, and growing season climate factors, such as average wind speed, daily mean temperatures, heat units, etc.

In this study, future irrigation water demand for crops was estimated by following ICDC [7] crop requirement data combined with an estimate of the growing season precipitation plus seedbed moisture. The estimated change in moisture deficit from climate change for 2040 was estimated to be 5 days at $2 \mathrm{~mm}$ and 10 days at $1 \mathrm{~mm}$, while for 2060 it was 15 days at $1 \mathrm{~mm}$ and 10 days at $2 \mathrm{~mm}$, to give a total deficit of $20 \mathrm{~mm}$ and $35 \mathrm{~mm}$ for 2040 and 2060, respectively. This provided the basis for moisture deficit for various crops for a normal year, 2040 and 2060.

In addition to increases in water demand because of higher temperatures and lower precipitation (or lower soil moisture), droughts can also increase water requirements for crops. A regression analysis of the SSRID irrigation water use per acre (IWD) for the period 1990 to 2009 was undertaken, using a binary variable (BY) for the 2001 and 2002 drought years. To account for any possible economies of size in distribution, irrigated area (AREA) was also included. A TIME (trend) variable was included to reflect any technological developments. Results are shown in Equation (1).

$$
\begin{aligned}
& \text { IWD }=259.15-11.34 \text { TIME }+0.018 \text { AREA }+178.38 * * \text { BY } \\
& \begin{array}{lll}
(313.17)(13.66) \quad(0.053) \quad(62.2)
\end{array} \\
& \mathrm{R}^{2}=0.437 \quad \mathrm{~F}=4.14^{*}
\end{aligned}
$$

where, ${ }^{* *}$ coefficient is significantly different from zero at $\alpha=0.01$;

* Hypothesis of all variables not affecting water demand rejected at $\alpha=0.05$.

The only significant coefficient in Equation (1) was that for the binary variable for 2001 and 2002 droughts. The increase during the 2001 and 2002 drought was, on average, $178.4 \mathrm{~mm}$ per acre, which is $68.8 \%$ over the water used during a normal year.

Future irrigation water demand in the basin will depend on the frequency of drought. Using past frequency of droughts in Saskatchewan at $8 \%$, and future frequency of $13 \%$ by 2040 and $18 \%$ by 2060 , and additional demand of $178.4 \mathrm{~mm}$ of water, water demand per acre of irrigated land for 2040 was adjusted up by 23 $\mathrm{mm}$ and that for 2060, by $32 \mathrm{~mm}$.

In this study, future irrigated area was estimated using announced plans plus estimates available from reliable sources. Currently, there are 347,849 acres of irrigation in the province, which is expected to increase to 849,903 acres by 2060 as "fill in" in the current irrigation districts and expansion in other areas. Much of the newer irrigation would deliver water using pivots, which is the most efficient manner of delivering water to the crops.

Under the baseline scenario, irrigation demand is estimated at $609,000 \mathrm{dam}^{3}$ of water. If by 2060 all planned irrigation projects are in place, irrigation water demand in the province would increase by slightly more than double the current level to 1.28 million dam ${ }^{3}$ (Table 1). When climate change effects are included in 
the forecast, irrigation water demand in Saskatchewan will jump to 1.6 million $\mathrm{dam}^{3}$ by 2060 . Thus, climate change would increase irrigation water demand by $25 \%$ by 2060 , although only a $15.7 \%$ increase is expected by 2040 .

Table 1: $\quad$ Estimated irrigation water demand by river basins, Saskatchewan, under a baseline scenario, 2010-2060.

\begin{tabular}{|c|c|c|c|c|c|}
\hline \multirow{2}{*}{ Scenario } & \multicolumn{4}{|c|}{ Amount of water demand in dam ${ }^{3}$} & \multirow{2}{*}{$\begin{array}{c}\% \text { change } \\
\text { in } 2060 \\
\text { over } 2010\end{array}$} \\
\hline & 2010 & 2020 & 2040 & 2060 & \\
\hline Baseline & 609,972 & 661,579 & $1,026,394$ & $1,281,258$ & $+110.1 \%$ \\
\hline Climate change & 609,972 & 661,579 & $1,187,891$ & $1,601,989$ & \\
\hline $\begin{array}{l}\% \text { change over } \\
\text { the baseline }\end{array}$ & 0.0 & 0.0 & +15.7 & +25.0 & \\
\hline
\end{tabular}

\section{Impact on dryland crop water demand}

Dryland farmers use water for spraying herbicides, and for general cleaning purposes. The first type of water demand is crop specific. Since farmers typically respond to price signals, and unless these prices for the future are known, the only tenable assumption is that the area for each of the crop categories - cereal, oilseed, and pulse, is expected to remain the same for the climate change scenarios in the future time period. This assumption can be supported by farmers following the crop rotation limitations. The major change that would be experienced under climate change is the adoption of zero tillage. This proportion may increase to $95 \%$ from $75 \%$ for cereals and pulses, and to $90 \%$ from $70 \%$ for oilseeds. The net effect of these changes is an increase in the water demand for pesticide application of $8 \%$ over the 2010 level by 2060 (Table 2). The indirect effect of climate change, higher evaporation, may make some surface water bodies that are currently used as a water source unsuitable, which may have some implications for water-based recreation activity and for domestic water demand.

Under the baseline scenario, this water demand was estimated at 1,492 $\mathrm{dam}^{3}$ per annum in 2010 , decreasing to $1,452 \mathrm{dam}^{3}$ by 2060 . This lessening occurs on account of assumptions made about adoption of zero tillage by Saskatchewan farmers, and about areas under summer fallow. Under climate change, this demand will increase to $1,579 \mathrm{dam}^{3}$ by 2060 . Thus, by 2060 climate change may induce an increase of $7.8 \%$ in water demand for dryland production. The increase in 2040 would be slightly lower - only $4.8 \%$ of the baseline water demand.

\section{Impact on stockwater demand}

Stockwater demand originates from two basic sources: the need for water by various types of animals, and general uses of water on a livestock farm. Under climate change both of these demand types will be affected. Total stockwater 
demand is a product of number of animals (by type) and their respective water requirement coefficients. For future water demand estimates, projections of animal numbers (by type) are needed. These were based on the estimated livestock populations and the estimated water demand coefficients as affected by climate change.

Table 2: Estimated provincial water demand for dryland farming, Saskatchewan, 2010-2060.

\begin{tabular}{|l|r|r|r|r|}
\hline \multirow{2}{*}{ Particulars } & \multicolumn{4}{c|}{ Amount of water demand in dam $^{3}$} \\
\cline { 2 - 5 } & \multicolumn{1}{|c|}{2010} & \multicolumn{1}{c|}{2020} & \multicolumn{1}{c|}{2040} & \multicolumn{1}{c|}{2060} \\
\hline Baseline & 1,492 & 1,470 & 1,452 & 1,452 \\
\hline Climate change & 1,492 & 1,503 & 1,521 & 1,579 \\
\hline Increase under climate change Scenario & $0 \%$ & $2.2 \%$ & $4.8 \%$ & $8.7 \%$ \\
\hline
\end{tabular}

\subsection{Impact on water demand for hogs}

Type of livestock, their age, climate, feed, and location on the farm (indoors/outdoors) are the factors that affect uptake of water. Each of the livestock types were treated separately in estimating future baseline and climate change scenario water demand. In addition, changes in water use technology for the production of various livestock types is also required for these estimations.

For hogs, climate change would bring forth the need for more cooling days relative to those for 2010 . It was estimated that by 2040 there will be $20 \%$ more days when cooling will be required, which will increase to $40 \%$ more such days by 2060 . The water required in 2060 will be about 36 litres per sow per day, which is $33.9 \%$ higher than that needed in 2010 .

The drinking water requirement of swine would also undergo some changes. Higher temperatures are expected to result in higher water consumption for the May to September period relative to the present situation. The change in drinking water use for these temperature changes suggest that a lactating sow, now needing only 15 litres of water per day, will need 35 litres per day if the increase in temperature is $3.5^{\circ} \mathrm{C}$ [8]. Combining this information, the final set of estimates was made, as shown in Table 3.

Table 3: Drinking water consumption for swine, by type of animal.

\begin{tabular}{|l|r|r|r|}
\hline \multirow{2}{*}{ Type of animal } & $\begin{array}{c}\text { Average } \\
1971-2000\end{array}$ & $\begin{array}{c}\text { Increase plus } \\
2{ }^{\circ} \mathrm{C}\end{array}$ & $\begin{array}{c}\text { Increase plus } \\
3.5^{\circ} \mathrm{C}\end{array}$ \\
\cline { 2 - 4 } & \multicolumn{3}{|c|}{ Litres day $^{-1}$ animal $^{-1}$} \\
\hline Gestating sows & 8.78 & 10.03 & 10.67 \\
\hline Lactating sows & 20.04 & 21.71 & 22.56 \\
\hline Suckling pigs & 0.71 & 0.85 & 0.92 \\
\hline Weaned pigs & 2.01 & 2.34 & 2.51 \\
\hline Growing finishing pigs & 6.76 & 7.35 & 7.65 \\
\hline Boars & 10.27 & 11.02 & 11.40 \\
\hline
\end{tabular}

Source: adapted from Thacker [8]. 


\subsection{Water demand for cattle}

Water consumption by cattle is affected by time of year, weight of the animal and feed type. The moisture content of feed affects the amount of additional water needed [9]. Assuming an increase in temperature of $2^{\circ} \mathrm{C}$ by 2040 , and $3.5^{\circ} \mathrm{C}$ by 2060 , the corresponding water requirements were estimated. These results are shown in Table 4.

Table 4: Estimated water demand coefficients for beef cattle.

\begin{tabular}{|l|r|r|r|r|}
\hline \multirow{3}{*}{$\begin{array}{c}\text { Animal } \\
\text { type }\end{array}$} & Type/Weight & \multicolumn{1}{c|}{$\begin{array}{c}\text { Average } \\
1971-2000\end{array}$} & Plus ${ }^{\circ} \mathrm{C}$ & \multirow{2}{*}{ Plus $4^{\circ} \mathrm{C}^{*}$} \\
\cline { 2 - 5 } & 182 & \multicolumn{3}{|c|}{ Litres day $^{-1} \mathrm{animal}^{-1}$} \\
\hline \multirow{3}{*}{ Background } & 277 & 19.05 & 20.38 & 21.54 \\
\cline { 2 - 5 } & 364 & 25.42 & 27.19 & 28.84 \\
\cline { 2 - 5 } & 273 & 29.73 & 31.85 & 33.67 \\
\hline Finishing & 364 & 34.93 & 30.50 & 32.28 \\
\cline { 2 - 5 } & 454 & 41.37 & 44.32 & 39.46 \\
\cline { 2 - 5 } & 409 & 35.36 & 36.38 & 46.74 \\
\hline Pregnant & 500 & 36.17 & 37.02 & 37.71 \\
\hline Lactating & 409 & 53.59 & 55.91 & 57.78 \\
\hline Bulls & 636 & 38.17 & 40.79 & 43.14 \\
\cline { 2 - 5 } & 727 & 41.37 & 44.22 & 46.74 \\
\hline
\end{tabular}

* Used as a proxy for $3.5^{\circ} \mathrm{C}$ temperature change.

\subsection{Water demand for dairy animals}

The water consumption estimates for dairy cattle used the categories of milk production, given the temperature, to arrive at water demand coefficients. These coefficients were then used to estimate water consumption for the three climate regimes, which are shown in Table 5. Water is also necessary for the cleaning of dairy operations, and it was estimated at 18.0 litres per cow per year [10].

Table 5: Estimated water demand coefficients for dairy cattle.

\begin{tabular}{|c|r|r|r|}
\hline \multirow{2}{*}{$\begin{array}{c}\text { Milk production in } \\
\mathrm{kg} / \text { day }\end{array}$} & Average 1971-2000 & Plus $2^{\circ} \mathrm{C}$ & Plus $4^{\circ} \mathrm{C}^{*}$ \\
\cline { 2 - 4 } & \multicolumn{3}{|c|}{ Litres day ${ }^{-1}$ animal $^{-1}$} \\
\hline 18.1 & 79.8 & 81.5 & 84.5 \\
\hline 27.2 & 92.6 & 94.3 & 97.6 \\
\hline 36.3 & 105.2 & 106.9 & 110.5 \\
\hline 45.4 & 118.0 & 119.78 & 123.7 \\
\hline
\end{tabular}

* Used as a proxy for a temperature change of $3.5^{\circ} \mathrm{C}$. 


\subsection{Water demand for poultry and other animals}

Water demand coefficients for alternative livestock and poultry as affected by temperature were not available, so the nearest animal type was used as a proxy. Water consumption coefficients for six categories of poultry were derived by the same methodology as that performed to estimate the coefficients for the beef and dairy sector. In addition, water is also needed in the cleaning of poultry operations and it is estimated at 1.7 litres per bird per year [10].

\subsection{Total stockwater demand}

Total stockwater demand for the basin under the climate change scenario is

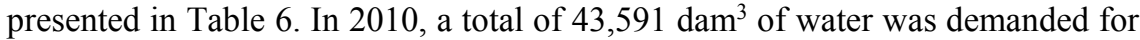
this purpose. By 2060, this measurement will experience growth, increasing to $50,106 \mathrm{dam}^{3}$ - an increase of $14.9 \%$ of the 2010 level. Under climate change scenario, water demand for livestock would increase further. By 2060, it is estimated that this demand would be $7.5 \%$ higher than the baseline level.

Table 6: Provincial livestock water demand, 2010-2060.

\begin{tabular}{|l|r|r|r|r|}
\hline \multirow{2}{*}{ Particulars } & \multicolumn{4}{|c|}{ Amount ( in dam $\left.^{3}\right)$} \\
\cline { 2 - 5 } & 2010 & 2020 & 2040 & 2060 \\
\hline $\begin{array}{l}\text { Water demand in dam } \\
\text { scenario under baseline }\end{array}$ & 43,591 & 46,604 & 48,477 & 50,106 \\
\hline $\begin{array}{l}\text { Water demand in dam } \\
\text { change scenario }\end{array}$ & 43,591 & 46,604 & 50,312 & 53,856 \\
\hline $\begin{array}{l}\text { Change in water demand under } \\
\text { climate change (\%) }\end{array}$ & 0 & 0 & +3.8 & +7.5 \\
\hline
\end{tabular}

The dairy and beef cattle sectors account for $79 \%$ of the total stockwater demand in the province, with the poultry and egg, along with the hog sector, accounting for $8 \%$ each.

\section{Other agricultural water demands}

In addition to the above three agricultural water demands, water is also used for greenhouses and nurseries, and for aquaculture activities. On account of controlled activities in greenhouses, and no impact of climate change on aquaculture activities, the water demands were assumed to be the same. However, nurseries will face a slight increase in their water demands. 


\section{Total agricultural water demand}

The five agricultural water demands are now aggregated to show total agricultural water demand in Saskatchewan. Results are shown in Table 7.

Table 7: Total agriculture water demand in Saskatchewan by type of demand and study scenarios, 2010-2060.

\begin{tabular}{|c|c|c|c|c|}
\hline \multirow{2}{*}{$\begin{array}{c}\text { Type of agricultural water } \\
\text { demand }\end{array}$} & \multicolumn{4}{|c|}{ Total water demand (in dam ${ }^{3}$ ) } \\
\hline & 2010 & 2020 & 2040 & 2060 \\
\hline & \multicolumn{4}{|c|}{ Baseline scenario } \\
\hline Irrigation & 609,972 & 661,579 & $1,026,394$ & $1,281,258$ \\
\hline Dryland demand & 1,492 & 1,470 & 1,452 & 1,452 \\
\hline Livestock & 43,591 & 46,604 & 48,477 & 50,106 \\
\hline Greenhouses and nurseries & 559 & 565 & 593 & 623 \\
\hline Aquaculture & 447 & 447 & 447 & 447 \\
\hline \multirow[t]{2}{*}{$\begin{array}{l}\text { Total agriculture water } \\
\text { demand }\end{array}$} & 656,062 & 710,664 & $1,077,363$ & $1,333,885$ \\
\hline & \multicolumn{4}{|c|}{ Climate change scenario } \\
\hline Irrigation & 609,972 & 661,579 & $1,187,891$ & $1,601,989$ \\
\hline Dryland production & 1,492 & 1,503 & 1,521 & 1,579 \\
\hline Livestock & 43,591 & 46,604 & 50,312 & 53,856 \\
\hline Greenhouses \& nurseries & 559 & 565 & 593 & 623 \\
\hline Aquaculture & 447 & 447 & 447 & 447 \\
\hline $\begin{array}{l}\text { Total agriculture water } \\
\text { demand }\end{array}$ & 656,062 & 710,697 & $1,240,763$ & $1,658,493$ \\
\hline $\begin{array}{l}\text { Change under climate } \\
\text { change scenario }\end{array}$ & $0 \%$ & $0 \%$ & $15.2 \%$ & $24.3 \%$ \\
\hline
\end{tabular}

The total water demand by the agriculture sector under baseline conditions would increase from $656,000 \mathrm{dam}^{3}$ to 1.33 million dam ${ }^{3}$ - an increase of $103 \%$ over the 2010 level. Much of this increase in irrigation would be as a result of irrigation projects within the Lake Diefenbaker Development Area, and as a result of diversion from Lake Diefenbaker to the Qu'Appelle River Basin. Irrigation water demand accounts for $93 \%$ of the total and is the only major demand among all agricultural water demands. Total water demands under the climate change scenario would increase further by $24.3 \%$ in 2060 . The increases over the 2010-2060 period are shown in Figure 1. 


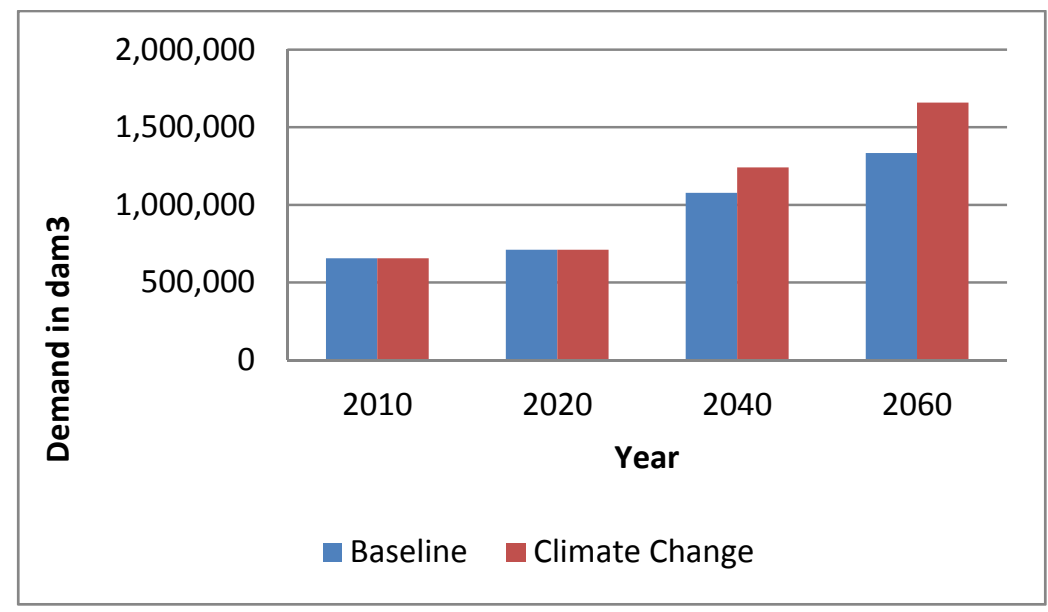

Figure 1: Total agricultural water demand in Saskatchewan, 2010-2060, baseline and climate change scenarios.

\section{Implications for policy making}

Water availability is a major factor affecting water demand, either through market prices or through the cost of obtaining it. Although policies can be developed to enhance water availability, a major impact on water supply-demand balance can be achieved by water demand management. The literature is full of suggestions for demand management although the use of market or non-market instruments is preferred.

Within the total agricultural water use, irrigation water demand presently accounts for $93 \%$ of the total amount of water demanded for the production of agricultural commodities in Saskatchewan. Very little evidence exists on who the users are and what their water use efficiency is. A slight improvement in the efficiency of this water use can solve many scarcity issues in the region. Climate change could affect the demand for water from agricultural operations by increasing water demand to $124 \%$ of the 2060 baseline projections. While water conservation options, if implemented, could reduce agricultural water demand, much depends on policies and regulations. Water conservation policies for irrigation through improving water use efficiency would be critical for this purpose.

\section{References}

[1] Frankhauser, S., Valuing climate change - the economics of the greenhouse. London: Earthscan Publication. 1995.

[2] IPCC - Intergovernmental Panel on Climate Change. Summary for Policy Makers. Prepared by L. Alexander, S. Allen, N. L. Bindoff, F-M Bréon, J. Church, U. Cubasch, S. Emori, P. Forster, P. Friedlingstein, N. Gillett, J. 
Gregory, D. Hartmann, E. Jansen, B. Kirtman, R. Knutti, K. Kanikicharla, P. Lemke, J. Marotzke, V. Masson-Delmotte, G. Meehl, I. Mokhov, S. Piao, G-K. Plattner, Q. Dahe, V. Ramaswamy, D. Randall, M. Rhein, M. Rojas, C. Sabine, D. Shindell, T. F. Stocker, L. Talley, D. Vaughan, S-P Xie. Report of the Twelth Session of Working Group I. Geneva. 2013.

[3] Waggoner, P., The Issues. In Waggoner, P. E. (ed.). Climate Change and U.S. Water Resources. New York: John Wiley and Sons, 1990.

[4] Lemmen, D. \& F. Warren, (2004). Climate Change Impacts and Adaptation: A Canadian Perspective. Ottawa: Natural Resources Canada.

[5] Sheffield, J. and E. Wood, Projected changes in drought occurrence for the future global warming from multi-model, multi-scenario, IPCC AR4 simulations. Climatic Dynamics 13: pp. 79-105, 2008.

[6] Wheaton, E., V. Wittrock, S. N. Kulshreshtha, G. Koshida, C. Grant, A. Chipanski, B. Bonsal, P. Adkins, G. Bell, G. Brown, A. Howard and R. MacGregor, (2005). Lessons Learned from the Canadian Drought Years 2001 and 2002: Synthesis Report. Saskatoon: Agriculture and Agri-Food Canada.

[7] ICDC - Irrigation Crop Diversification Corporation, Irrigation Scheduling Manual. Saskatchewan Ministry of Agriculture, Irrigation Crop Diversification Corporation, Outlook: Saskatchewan Ministry of Agriculture, p. 24, 2008.

[8] Thacker, P. A., Water in swine nutrition. pp. 381-398. In: A. J. Lewis and L. Southern (ed.). Swine Nutrition. 2nd ed., New York: CRC Press, 2011.

[9] Olkowski, Andrew A., Livestock Water Quality: A Field Guide for Cattle, Horses, Poultry and Swine. Agriculture and Agri-Food Canada publication A22-483/2009E. p. 181, 2009.

[10] Beaulieu, M.S, C. Fric and F. Soulard, Estimation of Water Demand in Canadian Agriculture in 2001. Agriculture and Rural Working Paper Series Environment Accounts and Statistics Division, Ottawa: Statistics Canada. p. 44, 2001. 